\title{
Editorial
}

\section{Jonathan Magonet}

2 018 saw the fiftieth anniversary of the spontaneous founding of an interfaith initiative involving Jews and Christians in the unlikely location of Germany. Anneliese Debray, who was the director of a Catholic women's adult education centre in Bendorf, near Koblenz, had the imagination and courage to set about creating programmes for encounter and reconciliation in the post-war world. The centre, the Hedwig Dransfeld Haus, became a meeting place for French and German and Polish and German families; for physically and mentally handicapped people together with 'normal' people; for the challenging task of ecumenical encounters between Catholic and Protestant Christians; for dialogue between Christians and Muslims; and eventually between Israeli and German young people. In that latter context the editor of this journal found himself visiting the centre and then, with two fellow rabbinic students at Leo Baeck College, attending an annual Catholic Bible study conference that summer. Our presence, our willingness to be there, and the rarity of such an opportunity for the participants, led to the desire to repeat the experiment the following year. Through incremental changes, the International Jewish-Christian Bible Week became an annual reality. ${ }^{1}$

After the death of Anneliese Debray, who had struggled for years to keep the Haus financially afloat, it went into bankruptcy. Nevertheless, what had been built had enough recognition and influence that it led to an invitation from Dr Uta Zwingenberger, who was responsible for Bible education in the Diocese of Osnabrück, to re-establish the Week in a new home, another Catholic adult education centre, Haus Ohrbeck, in the area of Osnabrück. There it continues to grow and flourish, hosting up to 130 people each year. Part of the impact, which makes it different from other more formal interfaith encounters, is the participation of families, with special programmes for children, so that the entire atmosphere is one of a normal human community.

Each year we restrict the number of formal lectures to three: one from each of the Jewish and Christian traditions, and one from some outside dimension, be it literature, psychotherapy, cultural history or contemporary issues. The range of papers given here well illustrates the 
breadth and depths of the insights and challenges that these biblical texts offer.

We regularly bring a selection of Bible Week's lectures together in an issue of the journal. ${ }^{2}$ The conference is conducted in both languages and papers originally written and delivered at the conference in German and included here were translated by Sr. Katherine Wolff nds and Rabbi James Baaden.

I need to explain the source of two sections here called 'Introductions' and 'Epilogues' which bear my name. Among the 'traditions' that have been built up over the years is that the editor, as a Bible scholar, and conscious of the ethos of the Week, provides a ten-minute introduction to the texts we are about to study during the opening evening. Similarly, at the end of the week, it has been his privilege to deliver an equally short sermon during the Shabbat morning service. Rather than preface and conclude each of the year's papers with these short individual pieces, I have run them together to top and tail the issue. (Given the anxiety that the word 'sermon' may raise in the mind of the average reader, and my attempt to reflect the ideas and moods that arose during the week, both serious and amusing, I have collected these under the more neutral title of 'epilogues'.)

The closing article by Larry Tabick, could well have found its place at the Week as he explores the opening words of the Ten Commandments in Midrashic and Chasidic commentaries.

When we were compiling this issue, we were deeply saddened by the death of two people who in very different ways were significant in the Jewish and wider community. Professor Ada Rapoport-Albert is best known in academic circles for her contribution to scholarship on Chasidism. Joanna Weinberg's 'In Memoriam' records this but also conveys something of the warmth and generosity of her personality. The editor first knew her back in the eighties when she made Hebrew translations of new English prayers and other passages destined for use in the High Holyday edition of the Machzor Forms of Prayer (1985) I was co-editing for the Reform Synagogues of Great Britain. The second person, Rabbi Willy Wolff, studied at Leo Baeck as a late 'second career' and went on to serve in the UK, and then to extraordinary acclaim in Germany. The extent of that success and the loving memory he leaves behind can be felt in the tributes paid in this issue. Both of them leave a memory that is truly a blessing.

Jonathan Magonet 


\section{Notes}

1. It is an interesting side note that the title 'Jewish-Christian' derived from the focus on the Hebrew Bible, and was unique in a situation where the usual designation of such encounters was 'Christian-Jewish' as the hosts in Germany were inevitably Christian institutions. In a sense, this correctly reflected the power differential between the two partners in the dialogue given the small size, self-confidence and state of knowledge of the German Jewish community.

2. Two papers that would belong in this issue have been previously published in European Judaism. In 2015, the paper given by Joanna Weinberg, 'Ecclesiastes 3:15 and a Homily on Persecution', appeared in Volume 49, No. 2 (Autumn 2016), 127-134. In 2016, the paper given by Jeremy Schonfield, 'Psalms 113-118: Qualified Praise?', appeared in Volume 50, No. 2 (Autumn 2017), $147-157$. 